\title{
Spatial variability of environmental isotope and chemical content of precipitation in Jordan and evidence of slight change in climate
}

\author{
William Bajjali
}

Received: 28 December 2011/Accepted: 15 May 2012/Published online: 5 June 2012

(C) The Author(s) 2012. This article is published with open access at Springerlink.com

\begin{abstract}
The spatial variability of the $\delta^{18} \mathrm{O}$ and $\delta \mathrm{D}$ compositions of rain is attributed to variations in amount of precipitation (PPT), altitude effect, and air masses originating from different sources. Air masses that enter the area passing the Mediterranean Sea result in higher d-excess. The cold and dry continental air masses originating from the European continent come in contact with the warm Mediterranean Sea water, resulting in rapid evaporation and large scale convergence. The low d-excess value is less than $16 \%$ and associated with air masses that cross over the North African continent and controlled by a local orographic effect. The change in isotopic composition of $\delta^{18} \mathrm{O}$ in PPT with altitude is $-0.15 \%$ per $100 \mathrm{~m}$. A statistical model confirms that a slight decrease in annual average precipitation has occurred since 1988 and attributed to a minor change in climate. The current level of tritium in rain corresponds to the average level of tritium in the atmosphere. Rabba station recorded a twofold higher tritium concentration in 1995 than the other stations, which may be from leakage from a nuclear station in Israel. The chemistry of rainwater demonstrates a wide range of salinity (100-600 mg/l). The lowest solute concentrations are found at high elevations, and the highest solute concentrations are found in the eastern desert and the Jordan Rift valley. The salinity of rain is affected by desert dust, aerosols, amounts of PPT, and the direction of rain fronts. The aerosols and windblown soil are the most prevailing as
\end{abstract}

\footnotetext{
W. Bajjali ( $\square)$
}

Department of Natural Sciences, University of Wisconsin, Superior,

Belknap \& Catlin, PO Box 2000,

Superior, WI 54880, USA

e-mail: wbajjali@uwsuper.edu the country is confined between three seas and the outcrop surficial geology is mainly sedimentary rocks.

Keywords Environmental isotope - Precipitation · Hydrochemistry $\cdot$ Climate change

\section{Introduction}

Water resources in Jordan are limited and mainly sourced from groundwater. Precipitation (PPT) is vital and the primary source of recharge for various groundwater aquifers in Jordan. The hydrogen and oxygen isotopic composition of rainwater and variations in amounts of PPT can be helpful to discern the physical processes affecting PPT. Moisture in the atmospheric originates from oceans where its chemical composition is determined by isotopic effects related to evaporation and condensation between ocean water and the atmosphere (Boyle 1997). Evaporation, cooling, condensation, and rainout occur by different meteorological processes such as transportation from oceanic to continental regions, orographic lifting, and convective processes (Rozanski et al. 1993). The isotopic composition of the vapor in the atmosphere can be also further modified by mixing with evaporated meteoric water (Gat et al. 1994).

The stable oxygen and hydrogen isotope compositions of meteoric water exhibit spatial variation all over the Earth. Understanding the evolution of $\delta^{18} \mathrm{O}$ and $\delta \mathrm{D}$ compositions of PPT through primary evaporation, condensation, re-evaporation, and infiltration is essential for hydrological studies. Isotopic models of PPT are generally based on the Rayleigh fractionation mechanism: as rain or snow falls from the cloud, depletion in oxygen-18 and deuterium is observed in the residual condensed air mass and thus in subsequent PPT (Dansgaard 1964; Gat 1980). 
On a global average, the general relationship between ${ }^{18} \mathrm{O} /{ }^{16} \mathrm{O}$ and ${ }^{2} \mathrm{H} /{ }^{1} \mathrm{H}$ for natural waters in PPT at a particular site over time is linear and expressed by the global meteoric water line (Craig 1961):

$\delta \mathrm{D}=8 \delta^{18} \mathrm{O}+10 \%$

Deviation from the global meteoric water line (GMWL) is defined by a local meteoric water line (LMWL), which can be expressed by deuterium excess (Dansgaard 1964).

The d-excess $=\delta \mathrm{D}-8 * \delta^{18} \mathrm{O}$

The d-excess can be used to identify vapor source regions, which may vary seasonally (Dansgaard 1964). The d-excess is regarded as the most useful stable isotope property for characterizing the vapor origin of water (Gat and Carmi 1970). Low d-excess values of PPT reflect slow evaporation at its source region due to high humidity, whereas high values reflect fast evaporation due to low humidity and re-evaporated moisture from continental basins to the water vapor traveling inland (Clark and Fritz 1997).

In the eastern Mediterranean, the d-excess value is higher than 10 because evaporation processes at the sea surface occur into low-humidity air masses of continental origin. The oxygen-hydrogen isotope relationship has been expressed by the Mediterranean meteoric water line (MMWL), $\delta \mathrm{D}=8 \delta^{18} \mathrm{O}+22$ (Gat 1980; Gat and Carmi 1987). The location of the data on the LMWL indicates the origin of the air moisture. PPT throughout the eastern Mediterranean area shows a different correlation between $\delta^{18} \mathrm{O}$ and $\delta \mathrm{D}$ with, d value of $\sim 22 \%$ (Gat and Carmi 1970).

Tritium is a radioactive isotope of hydrogen $\left({ }^{3} \mathrm{H}\right)$, and has a half-life of 12.43 years. It is produced in the upper atmosphere by the interaction of cosmic ray-produced neutrons with nitrogen atoms. The tritium content of atmosphere has increased greatly since 1952 owing to thermonuclear explosions in the northern hemisphere, which makes it a useful tool to elucidate the residence time of recently recharged groundwater.

Realizing the importance of the basic data on isotopic composition of PPT to hydrology, we collected and analyzed data on $\delta^{18} \mathrm{O}, \delta \mathrm{D}$, tritium, and chemical analysis from PPT on a monthly basis for various years from 11 rainfall stations all over the country. The main goal of this study was to provide an index of the isotopic and chemical compositions to understand the spatial distribution of isotopes and its variation through time in a small scale area like Jordan. Furthermore, the collected isotope data can be used in different hydrological investigations.

Jordan lies climatically within the Mediterranean Bioclimatic region with a concentration of rainfall during the cool wet winter season and a very marked summer drought.
This relatively simple climatic regime is caused by the interaction of two major atmospheric circulation patterns. During the winter months, Jordan is within the sphere of influence of the temperate latitude climatic belt, and cool, moist air moves eastward from the Mediterranean over the area. In the summer months, the area lies within the subtropical high pressure belt of dry high temperatures (Meteorological Department of Jordan 1998). Rainfall over Jordan varies where autumn/spring rains are associated with Mediterranean air and originate from the Atlantic Ocean. Winter rains are associated with continental polar air masses and originate from the Russian land in the north; air masses pick up moisture from the Black and Aegean seas. The desert in the eastern part of the country experiences very minimal rain due to the rain-shadow effect of the eastern steeper mountains. This area averages less than $100 \mathrm{~mm}$ of annual PPT. Rain decreases from an average of $600 \mathrm{~mm} /$ year in Ras Muneef to $\sim 250 \mathrm{~mm} /$ year in Deir Alla in the Jordan Rift valley (JRV), within an aerial distance of $10 \mathrm{~km}$ and a difference in altitude of around $1,300 \mathrm{~m}$. The rate of decrease in rainfall to the east is even more dramatic and usually from $300 \mathrm{~mm} / \mathrm{year}$ at the Shoubak to $100 \mathrm{~mm} /$ year within $30 \mathrm{~km}$ distance to the east (Fig. 1).

PPT in Jordan falls normally in the form of rainfall. Snowfall occurs generally once or twice a year over the highlands. The rainy season extends from October to April, with the peak of PPT taking place during January and February. Average temperatures increase gradually from the dissected plateau to the eastern margins of the eastern desert, and decrease gradually from South to North parallel with increasing latitude.

\section{Sampling and analysis}

The current study analyzes oxygen and hydrogen isotopic data (including radioactive tritium) of PPT that were collected from different sources. One set of the data has been collected from four stations during the time period between 1965 and 1969 and also from unpublished data of the International Atomic Energy Agency (IAEA). A second set of data covers 11 stations and it has been collected between 1987 and 1989 (Fig. 2; Bajjali 1990; Bajjali 1994; Bajjali et al. 1997). A third set of data has been obtained from the monitoring program of the Water Authority of Jordan (WAJ), which was collected inconsistently between 1990 and 2005. The IAEA data were measured in the IAEA laboratory in Vienna, and the rest of the data were measured in the laboratory of the WAJ (Appendix 1).

Figure 2 shows the distribution of the 11 rainfall stations in Jordan from which the PPT samples were taken. The stations range in elevation from $-224 \mathrm{~m}$ below the sea 
Fig. 1 Average annual rainfalls

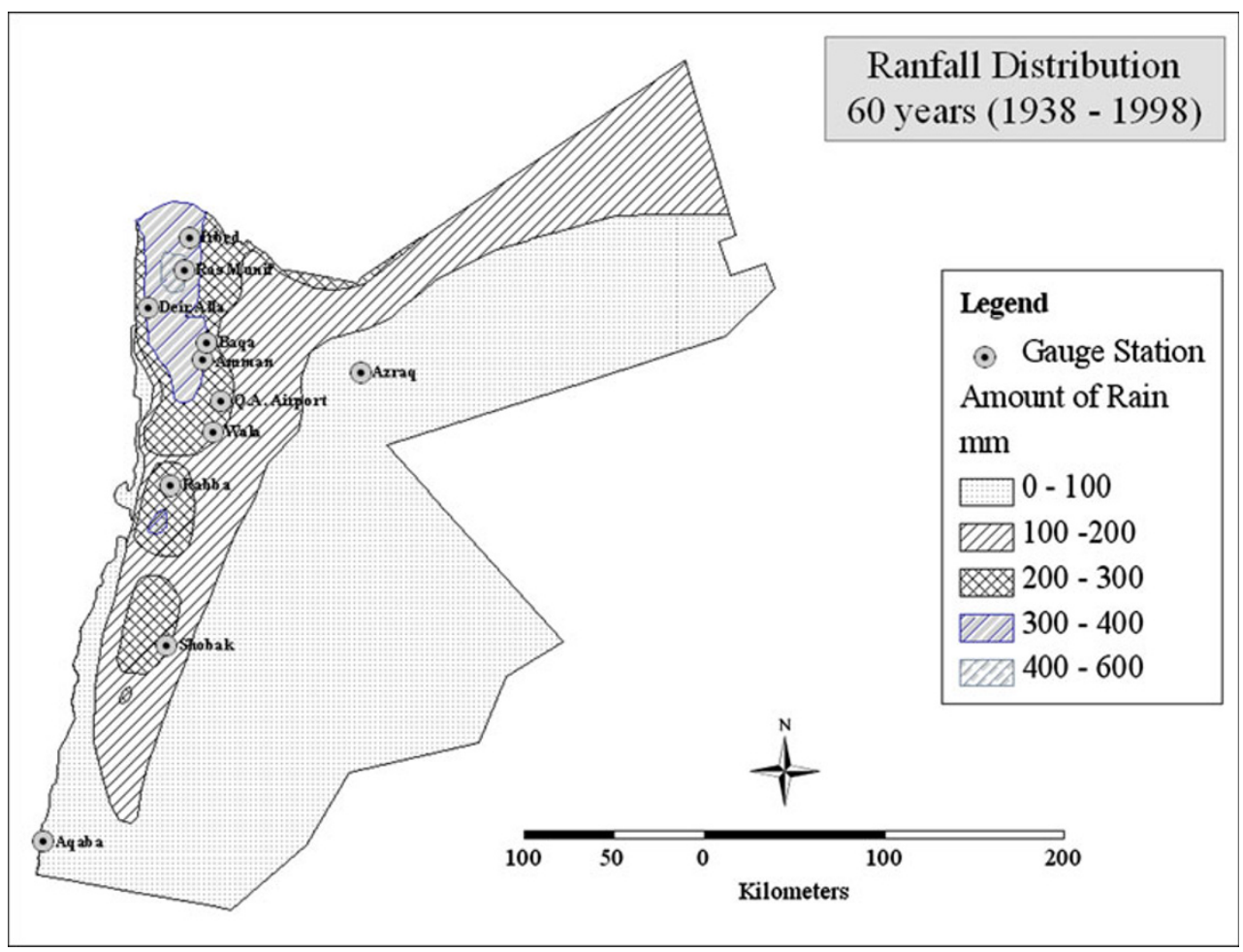

Fig. 2 Location of sampling rainfall gauge stations

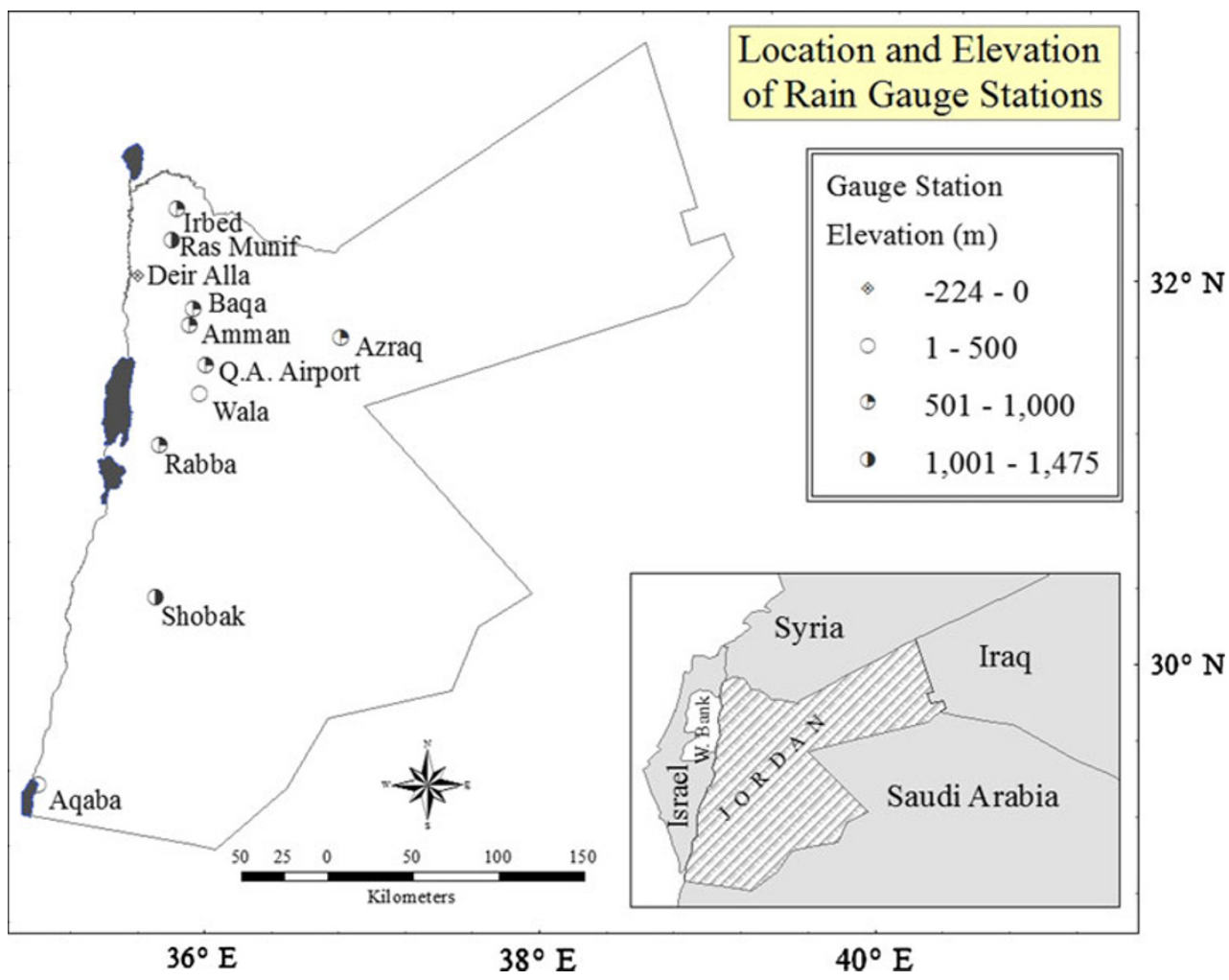

precautions to minimize possible isotopic exchange and/or evaporation of rainwater during collection in the gauge and during the storage of samples. PPT samples were analyzed for their major cations $(\mathrm{Na}, \mathrm{K}, \mathrm{Ca}$, and $\mathrm{Mg}$ ) and anions level to over 1,000 m above sea level (Table 1). Monthly water samples were collected during the rainy season from the 11 selected rainfall stations according to standard IAEA specifications. The sample collection procedure included

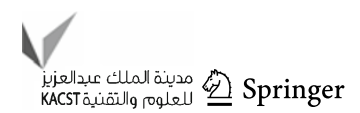


Table 1 Elevation and locations of the gauge stations

\begin{tabular}{llllc}
\hline ID & Gauge station & \multicolumn{2}{l}{ Coordinates } & Altitude $(\mathrm{m})$ \\
\cline { 3 - 4 } & & Longitude & Latitude & \\
\hline 1 & Deir Alla & 35.89 & 32.19 & -224 \\
2 & Aqaba & 35.29 & 29.45 & 40 \\
3 & Walla & 35.99 & 31.58 & 350 \\
4 & Azraq & 36.73 & 31.84 & 533 \\
5 & Irbed & 35.90 & 32.53 & 555 \\
6 & Baqa & 35.95 & 32.02 & 700 \\
7 & Q.A. Airport & 36.04 & 31.73 & 715 \\
8 & Amman & 35.99 & 31.95 & 900 \\
9 & Rabba & 35.75 & 31.31 & 970 \\
10 & Ras Munif & 35.91 & 32.38 & 1,150 \\
11 & Shobak & 35.71 & 30.50 & 1,475 \\
\hline
\end{tabular}

$\left(\mathrm{Cl}, \mathrm{HCO}_{3}, \mathrm{SO}_{4}\right.$, and $\left.\mathrm{NO}_{3}\right)$. Chemical composition of PPT provides valuable information on the prevailing state of the atmospheric environment in Jordan and about the sources that contribute to rainwater chemistry, and it therefore, enhances understanding of the dispersion of the ions through deposition processes. The $\delta \mathrm{D}$ and $\delta^{18} \mathrm{O}$ measurements were determined by mass spectrometry (Delta-E Finnegan Mat) with an overall precision of 1 and $0.15 \%$, respectively. The isotope results were reported as parts per thousand deviations of isotope ratios from Vienna Standard Mean Ocean Water (V-SMOW). Tritium was measured by a liquid scintillation spectrometer (Packard 3255) of water, previously enriched by electrolysis and concentrations are expressed in Tritium Units (TU). The error of measurement is \pm 1 TU. The amount of PPT and mean monthly temperatures are recorded for every gauge station.

\section{Results and discussions}

Variations in stable isotopic composition

Gat and Carmi (1970) calculated a LMWL for the eastern Mediterranean: $\delta D=8 * \delta^{18} \mathrm{O}+22$. The data presented here suggest a slightly different LMWL for Jordan (Fig. 3),

$\delta \mathrm{D}=6.27 \pm 0.11 * \delta^{18} \mathrm{O}+11.40 \pm 0.66$

The correlation coefficient $\left(R^{2}\right)$ equals $0.93(n=481)$ at $95 \%$ confidence level. The values represented in Fig. 3 are weighted mean values (WMV) for samples with PPT more than 5-mm rain and signify exactly the same period of time for both $\delta^{18} \mathrm{O}$ and $\delta \mathrm{D}$ (Table 2). The WMV were calculated following the equation.

$\delta \mathrm{O}^{18}=\frac{\sum_{i=1}^{n} P_{i} \delta_{i}}{\sum_{i=1}^{n} P_{i}}$ where $P_{\mathrm{i}}$ and $\delta_{\mathrm{i}}$ signify the collected amount of PPT and $\delta$ value, respectively.

The calculated slope of 6.27 indicates that the measured values do not simply fit the Rayleigh condensation process under equilibrium, which may imply that the WMV of the intense rains $(>5 \mathrm{~mm})$ was considerably influenced by vapor released from the Mediterranean Sea through a very fast evaporation process. The low value of d-excess (11.4) likely reflects the control of the mean condensation temperature of the heaviest rain. Therefore, the monthly PPT data points are scattered widely over the $\delta^{18} \mathrm{O}-\delta \mathrm{D}$ diagram. The $\delta^{18} \mathrm{O}$ and $\delta \mathrm{D}$ vary widely, between 1.39 and $-9.27 \%$ and between -2.39 and $-52.81 \%$, respectively. The majority of the WMV of $\delta^{18} \mathrm{O}$ and the $\delta \mathrm{D}$ follow the MMWL trend, although considerable deviation is observed (Fig. 3).

It is clear that all data points do not lie along one single line in the $\delta^{18} \mathrm{O}-\delta \mathrm{D}$ diagram. This might be due to the patterns of cooling as well as the initial dew points. Similar spatial variation phenomenon have been observed and documented at different locations worldwide and attributed to various factors such as temperature of condensation (Dansgaard 1964; Hartley 1981), origin of air mass vapor (Gat and Dansgaard 1972), and evaporation and isotopic exchange between falling rain and atmospheric water vapor (Stewart 1975). The first review of the Jordanian database revealed that the observed pattern of distribution of $\delta^{18} \mathrm{O}$ and $\delta \mathrm{D}$ is related to a number of environmental factors such as altitude, surface air temperature, and distance from the coast (Bajjali 1990). Figure 3 shows that the points lying below the MMWL demonstrate enriched isotopic values and they belong mainly to stations from Deir Alla, Aqaba, and Azraq and the PPT's at these locations have low d-excess values. Data points from Deir Alla, Aqaba, and Azraq have a reduced deuterium excess value $(<16)$ relative to the rest of the stations.

The isotopic composition of PPT clusters into three groups (Fig. 4), group 1 is enriched in $\delta^{18} \mathrm{O}$ and the $\mathrm{d}$-excess value has an average of $15.75 \%$, group 2 is much depleted in $\delta^{18} \mathrm{O}$ and the d-excess value has an average of $24 \%$, and group 3 plots between the first and second groups. Group 1 reflects the data collected from Deir Alla, Aqaba, and Azraq. These stations are characterized by a low altitude (Deir Alla at $224 \mathrm{~m}$ below sea level, Aqaba at sea level and Azraq at $553 \mathrm{~m}$ above sea level in the eastern desert and within the range of the rain shadow). Group 2 is characterized by two stations at high elevations, Ras Munif $(1,150 \mathrm{~m}$ above sea level) and Shobak (1,475 $\mathrm{m}$ above sea level). Group 3 includes the rest of the gauge stations at altitudes between 350 and $970 \mathrm{~m}$ above sea level. The $\delta^{18} \mathrm{O}$ values form group 2 varies between -8.25 and $-2.97 \%$ and has average d-excess values of around $22.8 \%$. 
Fig. $3 \delta^{18} \mathrm{O}-\delta \mathrm{D}$ diagram of precipitation in Jordan

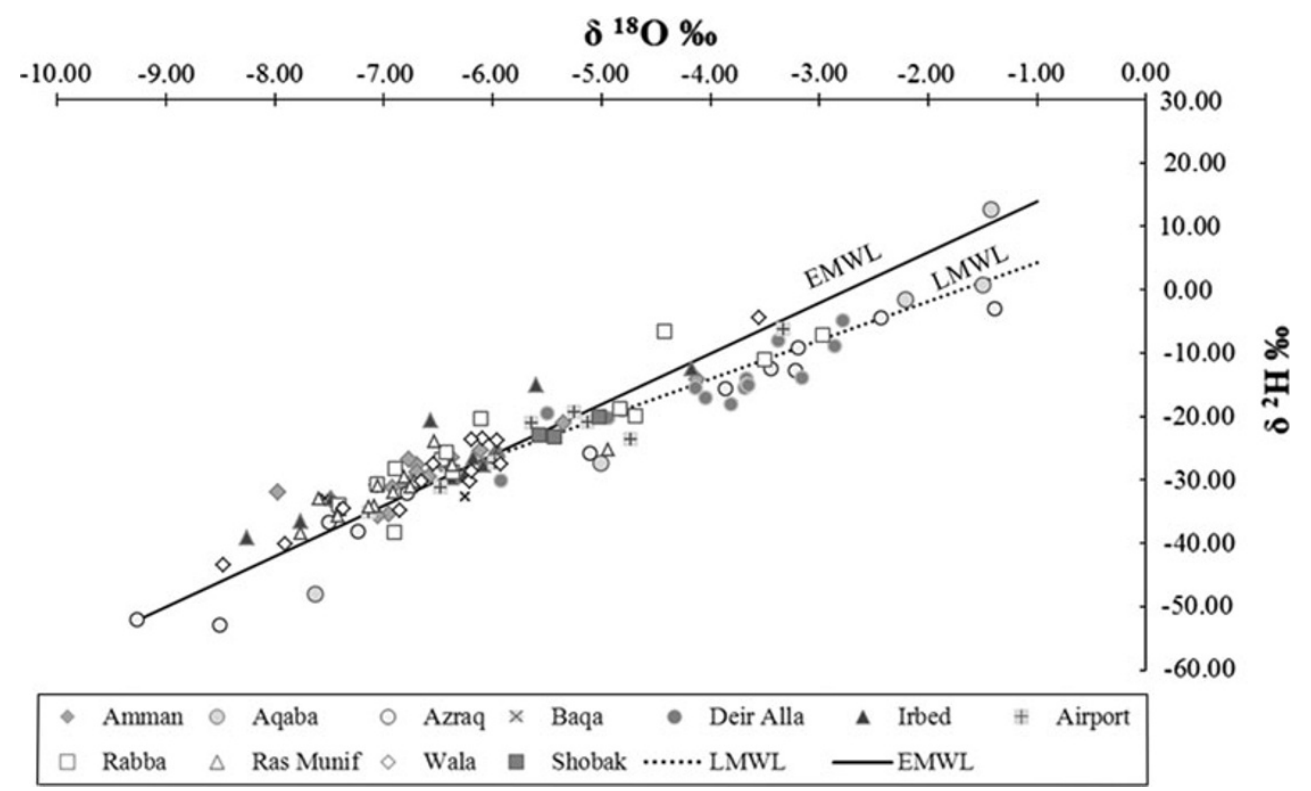

Table 2 Weighted mean values for rain higher than $5 \mathrm{~mm}$

\begin{tabular}{|c|c|c|c|c|c|c|}
\hline ID & Gauge station & $\delta^{18} \mathrm{O}$ & $\delta \mathrm{D}$ & $\begin{array}{l}\# \text { of }{ }^{18} \mathrm{O} \text { and } \\
\mathrm{D} \text { samples }\end{array}$ & $\mathrm{TU}$ & $\begin{array}{l}\text { \# of tritium } \\
\text { samples }\end{array}$ \\
\hline 1 & Deir Alla & -3.73 & -15.04 & 55 & 6.88 & 59 \\
\hline 2 & Aqaba & -3.01 & -7.98 & 6 & 13.03 & 6 \\
\hline 3 & Wala & -5.84 & -27.22 & 20 & 10.68 & 32 \\
\hline 4 & Azraq & -5.16 & -24.56 & 31 & 9.41 & 14 \\
\hline 5 & Irbed & -6.36 & -26.98 & 68 & 5.14 & 82 \\
\hline 6 & Baqa & -4.54 & -12.74 & 6 & 7.18 & 6 \\
\hline 7 & Q.A.Airport & -5.56 & -23.65 & 25 & 7.87 & 31 \\
\hline 8 & Amman & -6.49 & -27.84 & 90 & 30.17 & 105 \\
\hline 9 & Rabba & -5.70 & -22.77 & 43 & 34.71 & 55 \\
\hline 10 & Ras Munif & -6.86 & -30.38 & 66 & 5.20 & 84 \\
\hline 11 & Shobak & -6.71 & -30.35 & 34 & 6.45 & 48 \\
\hline
\end{tabular}

The overall trend line for all of samples is expressed by the linear regression equation: $\mathrm{d}=-1.86 \delta^{18} \mathrm{O}+10.56 \%$ o $\left(R^{2}=0.44\right)$.

The features of the oxygen and hydrogen isotope data suggest that air masses from different sources have significantly influenced the pattern of data. The air masses that enter the area passing the Mediterranean Sea result in higher d-excess. The cold and dry continental air masses originating from the European continent come in contact with the warm Mediterranean Sea water, resulting in rapid evaporation and large scale convergence. The low d-excess value that is less than $16 \%$ is likely associated with air masses that cross over the North African continent and with a local orographic effect. The relatively low correlation $\left(R^{2}=0.44\right)$ between $\delta^{18} \mathrm{O}$ and d-excess value suggests complex relationship that requires more data representing single event rains and vertical atmospheric profiles in order to reach more conclusive interpretations.
Altitude effect

Spatial distribution of $\delta^{18} \mathrm{O}$ and the $\delta \mathrm{D}$ in the region is also dominated by the altitude effect due to orographic lifting (Fig. 5). The eastern highlands along the JRV obstruct the air masses that pass over the Mediterranean and force them to rise. The rising air cools and condenses the moisture along the slope as the air is driven upward over the mountains and falling temperatures cause the air to lose much of its moisture which leads to less PPT. Therefore, Azraq station receives less rain as it is located in the rain shadow.

A continuous depletion of $\delta^{18} \mathrm{O}$ associated with the increase in elevation has been observed in the samples collected along a cross section from the JRV at Deir Alla to the eastern desert at Azraq, passing the eastern highland at Ras Munif. A similar trend that has been also observed in the isotopic composition of the air masses ascending over 
Fig. 4 d-excess versus $\delta^{18} \mathrm{O}$ in precipitation
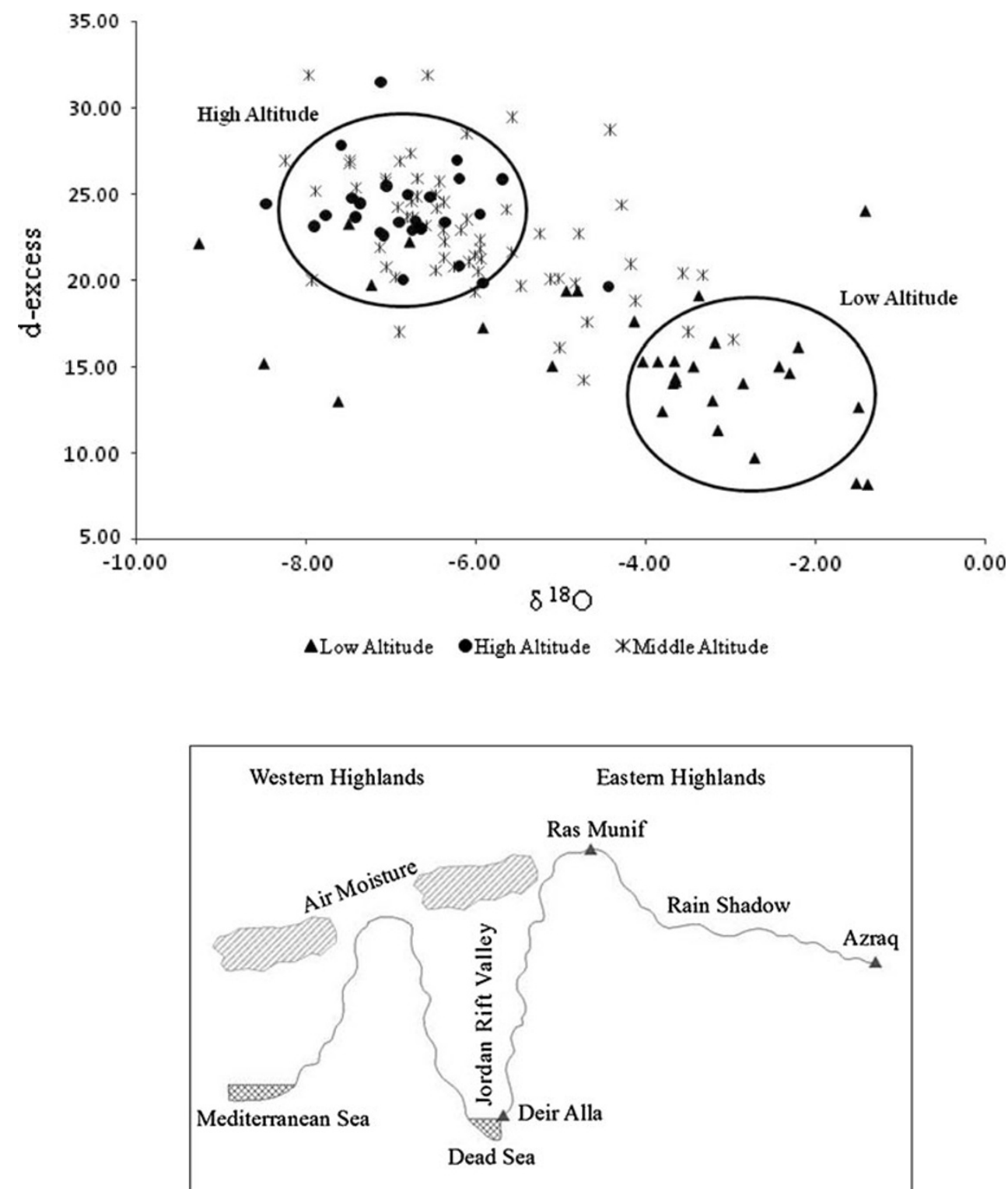

Deir Alla

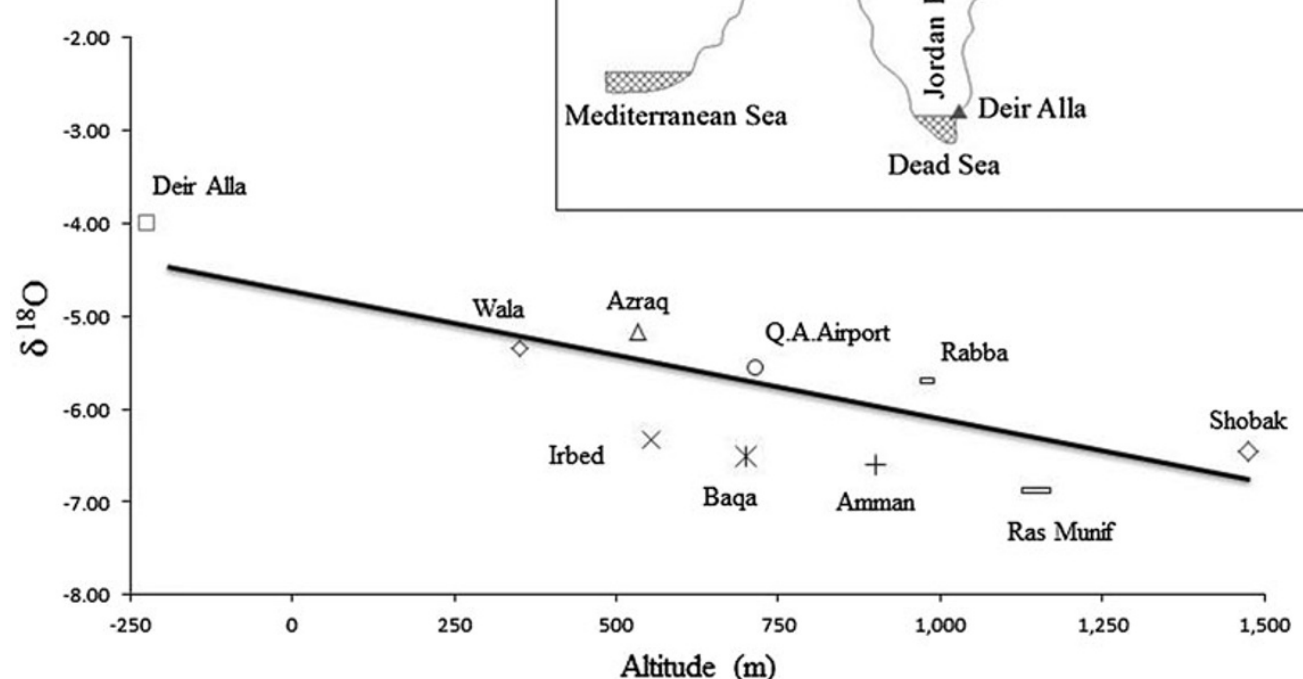

Altitude (m)

Fig. 5 The WMV of $\delta^{18} \mathrm{O}$ of rain as a function of altitude

Eastern Highlands and those descending counterparts in the rain-shadow area of Azraq. The WMV of $\delta^{18} \mathrm{O}$ values vary from $-3.73 \%$ in Deir Alla to $-6.86 \%$ in Ras Munif and
$-5.16 \%$ in Azraq. Since rains were collected from all stations at the same time, the rate of change in $\delta^{18} \mathrm{O}$ composition of PPT with altitude is $-0.15 \%$ per $100 \mathrm{~m}$. 


\section{Climate change and precipitation}

In general, wet regions are increasingly experiencing more PPT, and arid areas are becoming drier (Dore 2005). Annual average PPT is decreasing in most of the Mediterranean and northern Africa during winter (IPCC 2007). The amount of PPT in Jordan has decreased in winter times for the last two decades, which affects the total volume of water resources. This caused a $30 \%$ reduction in the country's surface water and a decrease in the agricultural production as well, which the country relies on heavily (Hadidi and Ismail 2010). Total annual PPT from 1971 and 2010 of the two stations in Amman and Mafraq is shown in Fig. 6. The general trend of the data in both stations indicates that the amount of rain has been decreasing since 1988. This is clearly shown in the 5th order polynomial trend lines. In order to answer the question of how well the polynomial trend line model signifies a genuine decrease in the amount of PPT, a Chisquare goodness-of-fit test was applied to the data using Microsoft (MS) Excel.

The test measures how the PPT is consistent with a Null Hypothesis (H0). The $\mathrm{H} 0$ at a significant level of 0.05 , indicates that amount of PPT are steady overtime since 1971. The test statistic is a Chi-square random variable $\left(\chi^{2}\right)$ defined by the following equation.

$\chi^{2}=\sum\left[\left(O_{i}-E_{i}\right)^{2} / E_{i}\right]$

where $O_{i}$ is the observed frequency count for the $i$ th level of the PPT variable.
$E_{i}$ is the expected frequency count for the $i$ th level of the PPT variable.

The average amounts of PPT in Amman and Mafraq stations for the period between 1971 and 2010 were 258.44 and 153.76, respectively. The average value of both stations was used to test the null hypothesis. The Chi test shows the probability of how often the amount of PPT fluctuates. The calculated $p$ values were $4.39 \times 10^{-235}$ and $2.02 \times 10^{-146}$ for Amman and Mafraq, respectively. Both the values are dramatically much lower than the $\alpha$ value of 0.05 , which leads to rejection of the null hypothesis that the PPT is steady over time since 1971.

It is also noteworthy to notice that the $\delta^{18} \mathrm{O}, \delta \mathrm{D}$, and d-excess values of the four rainfall stations of Amman, Irbed, Rabba, and Shobak for the period 1966-1969 were found to be slightly more enriched in the period between 1987 and 2005 (Table 3). The isotopic change could be attributed to a minor change in climate.

A $t$ test approach, using MS Excel, has been utilized to examine the difference among the d-excess values for the periods between 1965-1969 and 1987-2005, which allow assessing the statistical significance in variation of those values.

Table 4 summarizes the results when a $95 \%$ confidence limit $(\alpha=0.05)$ is adopted to test the variability of the d-excess values of the two mentioned periods and the analysis is based on the assumption that the means of both the d-excess values are equal.

The two-tailed $p$ values are given as 0.0398 , which is less than 0.05 for the d-excess values, suggesting that the difference is significant at the $5 \%$ level. Because the probability level is smaller than the $\alpha$ value $(0.05)$, the
Fig. 6 The amount of rain in Amman and Mafraq with the Polynomial Trend Line

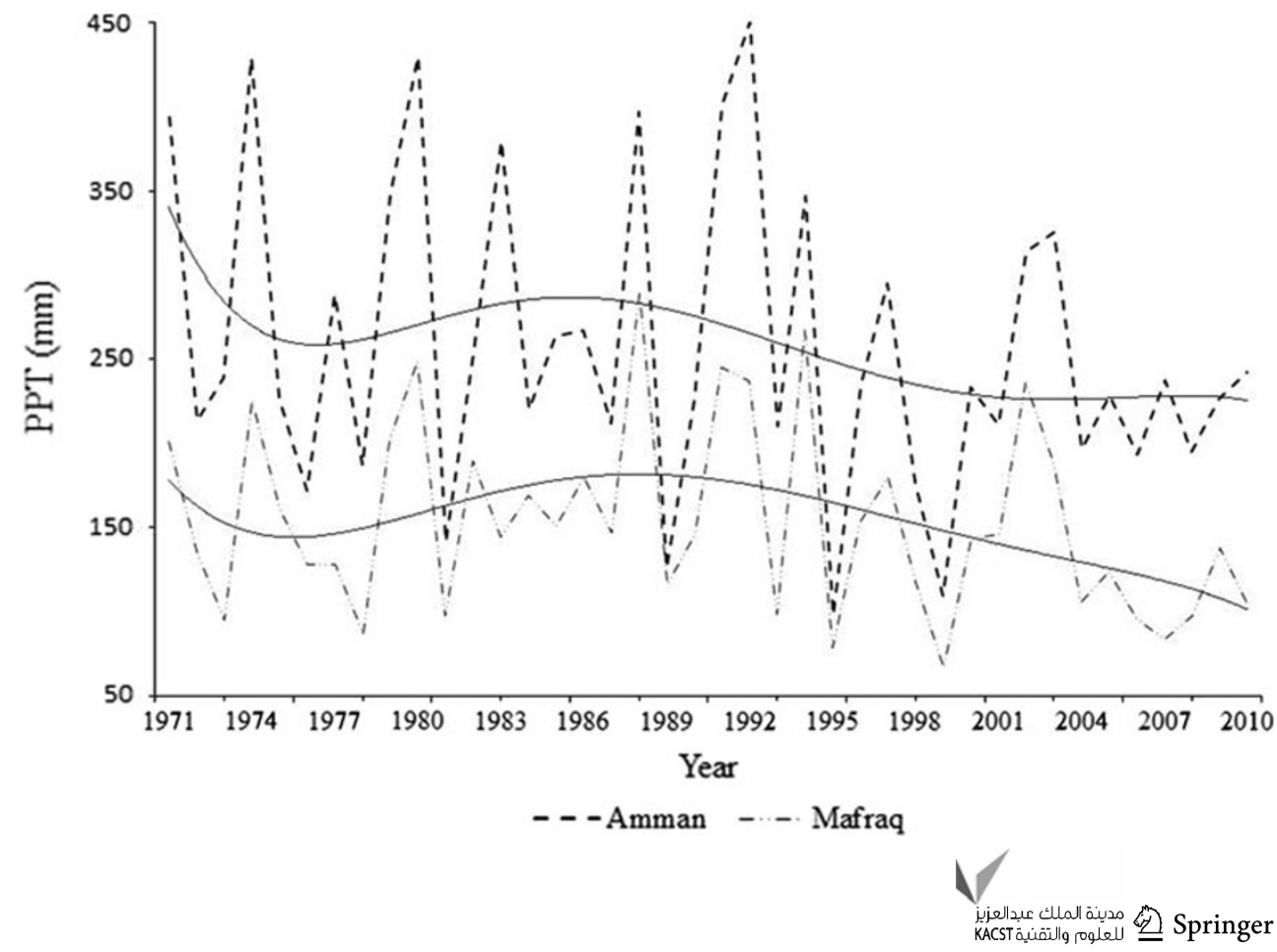


Table 3 Isotopic composition and d-excess comparison between two periods

\begin{tabular}{lllllllll}
\hline Gauge station & Years & $\delta^{18} \mathrm{O}$ & $\delta \mathrm{D}$ & $\mathrm{d}$ & Years & $\delta^{18} \mathrm{O}$ & $\delta \mathrm{D}$ & $\mathrm{d}$ \\
\hline Amman & $1965-1969$ & -6.19 & -26.67 & 22.8 & $1987-2005$ & -6.62 & -28.33 \\
Rabba & $1966-1968$ & -3.90 & -11.17 & 19.9 & $1987-2002$ & -6.50 & -27.93 \\
Shobak & $1967-1967$ & -5.36 & -19.40 & 23.4 & $1987-2003$ & -6.71 & -30.35 & 24.1 \\
Irbed & $1968-1967$ & -6.13 & -27.48 & 21.5 & $1987-2005$ & -6.52 & -28.02 & 24.2 \\
Average & & -5.39 & -21.18 & 21.9 & & -6.59 & -28.66 & 24.0 \\
\hline
\end{tabular}

Table 4 Result of the $t$ test assuming equal variance between the d-excess

\begin{tabular}{lcl}
\hline & $\begin{array}{l}\text { d-excess values } \\
(1965-1969)\end{array}$ & $\begin{array}{l}\text { d-excess values } \\
(1987-2005)\end{array}$ \\
\hline Mean & 21.9 & 24.05 \\
Variance & 2.4067 & 0.2967 \\
Observations & 4 & 4 \\
Pooled variance & 1.3517 & \\
Hypothesized mean difference & 0 & \\
df & 6 & \\
$t$ Stat & -2.6153 & \\
$\mathrm{P}(T<=t)$ one-tail & 0.0199 & \\
$t$ Critical one-tail & 1.9432 & \\
$\mathrm{P}(T<=t)$ two-tail & 0.0398 & \\
$t$ Critical two-tail & 2.4469 & \\
\hline
\end{tabular}

hypothesis of no difference between the d-excess values of the two periods seems inconsistent and the d-excess values of the two periods are therefore different.

\section{Tritium concentration in precipitation}

The available data for tritium in PPT in Jordan for the period of 1965-2005 show a general decrease of tritium, which reflects the global trend following the ban on atmospheric testing of hydrogen bombs in 1963 (Table 2). The current average value of tritium in the atmosphere is very low and reflects the yield of natural processes in the upper atmosphere and the past nuclear testing. Natural tritium production at the Earth's surface is estimated to occur at a rate of $0.1-1.3$ tritium atoms $/ \mathrm{cm}^{2} / \mathrm{s}$, with the most probable values occurring between 0.5 and 1.0 tritium atoms $/ \mathrm{cm}^{2} / \mathrm{s}$ (Zahn et al. 1998). Natural (pre-nuclear age) levels of tritium in PPT were on the order of 1-5 TU, where $1 \mathrm{TU}$ is equivalent to $3.231 \mathrm{pCi} / \mathrm{L}$ of water. The low level of tritium in the atmosphere will make this tool less reliable to be used in the near future for hydrological studies. Figure 7 presents the tritium levels in rain recorded at the Amman and Rabba stations and were very high between 1965 and 1969. The high level of tritium was due to nuclear-weapons testing. The highest recorded values were documented in 1966, but have declined steadily since the ban of nuclear testing.

The average tritium concentrations in the rain from the 11 rainfall stations after 1987 are $<6$ TU, with the exception for the value from Rabba, which was 14 TU (Fig. 8). The Rabba value is about twofold higher than the counterparts throughout the entire country, which suggests that there was an additional source of tritium besides natural production.

One possibility for such a high concentration would be leakage from a thermonuclear power plant close by the surrounding area. Rabba is located downwind and within a radius of $65 \mathrm{~km}$ from the Dimona Nuclear Research Center in Israel, meanwhile there is no nuclear plant in Jordan. It is very well documented that tritium is produced as a fission product in nuclear power reactors, with a yield of about $0.01 \%$ (EPA 2010). It would be important to analyze the PPT along a horizontal line between Dimona and Rabba.

\section{Hydrochemistry of precipitation}

Table 5 summarizes the statistics of the elemental analyses' results of Jordan rain water of the current study and Fig. 9 shows the distribution of the total dissolved solid values. The rainwater in the area contains wide range of chemical constituent, total dissolved solids (TDS) range from $16.45 \mathrm{mg} / \mathrm{l}$ in snow samples from Amman (January 2002) to $604 \mathrm{mg} / \mathrm{l}$ in rain samples from the same area (Feb 1999) with an average TDS value for all the samples of $98 \pm 8.15 \mathrm{mg} / \mathrm{l}$. The two extreme values, higher than $500 \mathrm{mg} / \mathrm{l}$, were recorded for Amman and Rabba rain in February 1999. Nevertheless, $67 \%$ of the samples have salinity concentrations $<100 \mathrm{mg} / \mathrm{l}$ and $30 \%$ of the samples are between 100 and $185 \mathrm{mg} / \mathrm{l}$. Despite the wide variations across the sampling locations, the higher elevation stations of Ras Munif and Shobak have lower TDS values among others.

The salinity of rain is affected by several factors including desert dust, aerosols, amount of PPT, and the direction of rain fronts. The aerosols are the most dominant factor as the country is surrounded by three major saline water bodies, the Mediterranean Sea, Red Sea, and the Dead Sea that has the most saline water on Earth. Aerosols 
Fig. 7 Tritium levels in Amman and Rabba between 1965 and 2005

Fig. 8 Tritium level in PPT in Amman and Rabba between 1987 and 2005
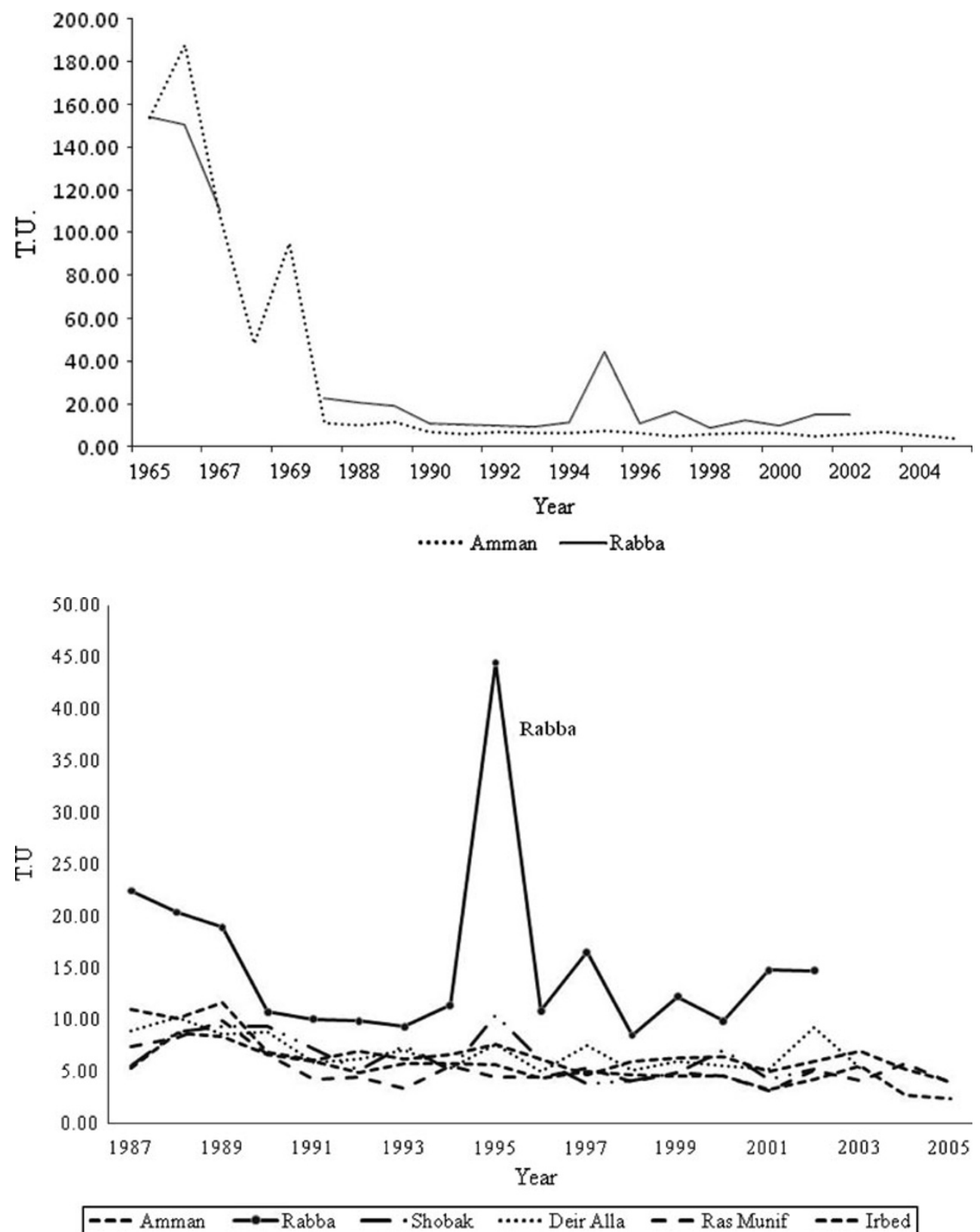

Table 5 Various descriptive statistics of major ions

\begin{tabular}{|c|c|c|c|c|c|c|c|c|c|c|c|}
\hline Statistics & $\begin{array}{l}\mathrm{EC} \\
(\mathrm{ms} / \mathrm{cm})\end{array}$ & $\begin{array}{l}\text { TDS } \\
\text { (ppm) }\end{array}$ & $p H$ & $\begin{array}{l}\mathrm{Ca} \\
(\mathrm{meq} / \mathrm{l})\end{array}$ & $\begin{array}{l}\mathrm{Mg} \\
(\mathrm{meq} / \mathrm{l})\end{array}$ & $\begin{array}{l}\mathrm{Na} \\
(\mathrm{meq} / \mathrm{l})\end{array}$ & $\begin{array}{l}\mathrm{K} \\
(\mathrm{meq} / \mathrm{l})\end{array}$ & $\begin{array}{l}\mathrm{Cl} \\
(\mathrm{meq} / \mathrm{l})\end{array}$ & $\begin{array}{l}\mathrm{SO}_{4} \\
(\mathrm{meq} / \mathrm{l})\end{array}$ & $\begin{array}{l}\mathrm{HCO}_{3} \\
(\mathrm{meq} / \mathrm{l})\end{array}$ & $\begin{array}{l}\mathrm{NO}_{3} \\
(\mathrm{ppm})\end{array}$ \\
\hline Sample no. & 97 & 97 & 98 & 98 & 98 & 69 & 69 & 98 & 98 & 98 & 94 \\
\hline Mean & 0.15 & 97.96 & 7.18 & 0.65 & 0.30 & 0.21 & 0.03 & 0.29 & 0.32 & 0.54 & 5.81 \\
\hline Standard error & 0.01 & 8.15 & 0.05 & 0.04 & 0.02 & 0.02 & 0.00 & 0.01 & 0.03 & 0.03 & 0.48 \\
\hline Median & 0.13 & 82.24 & 7.22 & 0.57 & 0.28 & 0.20 & 0.02 & 0.27 & 0.28 & 0.51 & 4.60 \\
\hline STDEV & 0.13 & 80.24 & 0.49 & 0.38 & 0.17 & 0.14 & 0.03 & 0.15 & 0.28 & 0.26 & 4.62 \\
\hline Skewness & 4.88 & 4.88 & 0.67 & 1.24 & 0.91 & 3.85 & 1.69 & 1.24 & 1.13 & 0.59 & 2.77 \\
\hline Range & 0.92 & 588.35 & 3.63 & 1.82 & 0.83 & 1.07 & 0.16 & 0.89 & 1.25 & 1.36 & 29.91 \\
\hline Minimum & 0.03 & 16.45 & 5.81 & 0.10 & 0.00 & 0.02 & 0.00 & 0.00 & 0.00 & 0.00 & 0.39 \\
\hline Maximum & 0.95 & 604.80 & 9.44 & 1.92 & 0.83 & 1.09 & 0.16 & 0.89 & 1.25 & 1.36 & 30.30 \\
\hline
\end{tabular}


Fig. 9 Frequency histogram for TDS

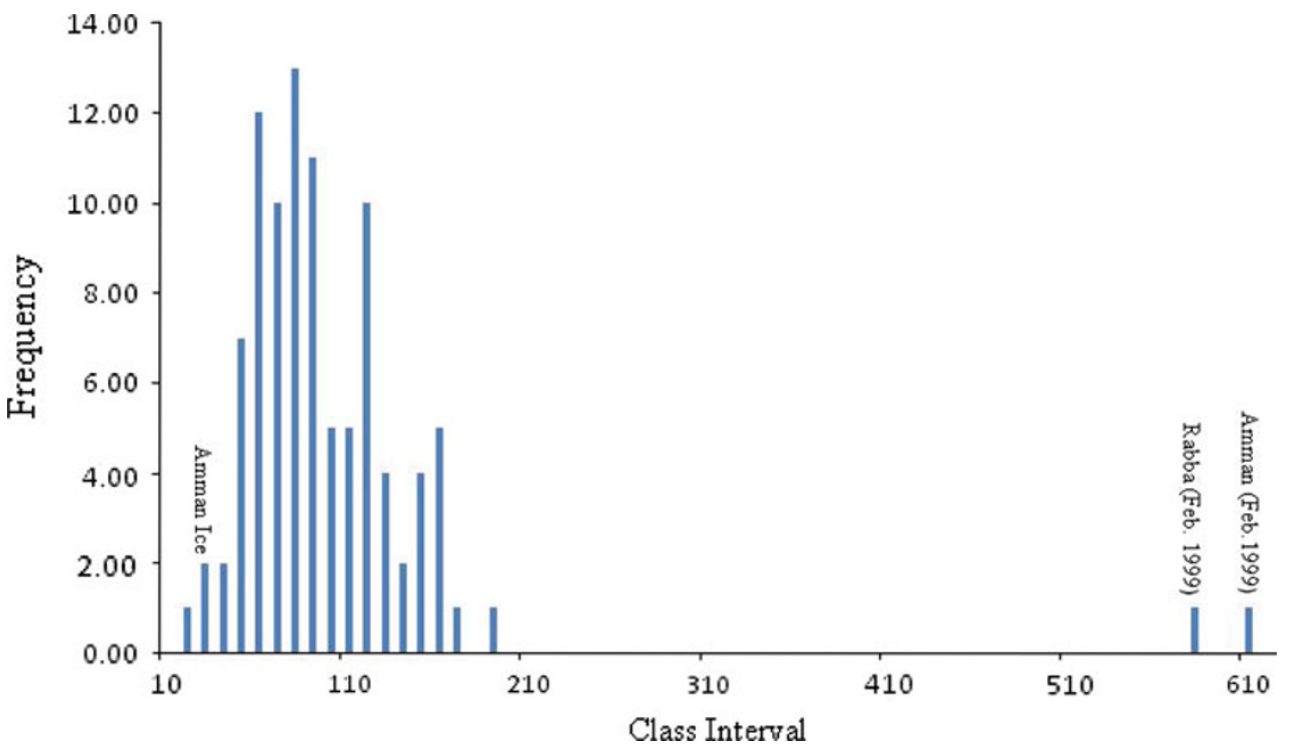

are tiny particles suspended in the air that occur naturally and can originate from dust storms or sea spray. Sea spray can be carried by wind for considerable distance and greatly influence the salinity of PPT in certain areas like the JRV. Windblown soil can also be a major contributing factor into salinity of PPT.

Presentation of data using a piper diagram (Fig. 10) reveals a wide range of hydrochemical facies. About $50 \%$ of the samples can be classified as $\mathrm{Ca}-\mathrm{HCO}_{3}, 16 \%$ as $\mathrm{Ca}-\mathrm{SO}_{4}, 16 \%$ as $\mathrm{Mg}-\mathrm{HCO}_{3}, 10 \%$ as $\mathrm{Ca}-\mathrm{Cl}, 5.37 \%$ as $\mathrm{Na}-\mathrm{HCO} 3$, and $2.15 \%$ as $\mathrm{Na}-\mathrm{Cl}$ facies. The samples show two dominant types of water. The first type is alkaline earth water with bicarbonate and chloride and the second type is alkaline earth water with prevailing chloride ion. The domination of $\mathrm{Ca}^{2+}, \mathrm{Mg}^{2+}$, and $\mathrm{HCO}_{3}{ }^{-}$ions suggests that the chemical composition of PPT has been influenced by that of the dust in the air, particularly, when the outcrop geology in the area is dominated by sedimentary rocks of Upper Cretaceous, which consist of limestone, dolomite, and marl.

Other samples recorded high concentrations of $\mathrm{Mg}^{2+}$, $\mathrm{Na}^{+}$, and $\mathrm{Cl}^{-}$, which are likely attributed to aerosols originating from regional saline water bodies, mainly the Dead Sea. The $\mathrm{SO}_{4}^{-2}$ concentration in the rain at Amman is relatively high compared to the other stations, which is most likely influenced by industrial gas effluent and the composition of burning fossil fuel from automobiles and houses in this area. The nitrate concentration in precipitation is generally very low. About $58 \%$ of the samples show nitrate concentrations of $<5 \mathrm{mg} / \mathrm{l}$, while $33 \%$ range between 5 and $13.5 \mathrm{mg} / \mathrm{l}$. Two high values of 23.79 and $30.3 \mathrm{mg} / \mathrm{l}$ were observed in Ras Munif and Deir Alla in January 2004 and in January 1987, respectively. These areas have intensive agricultural activities, and dust storms carrying fertilizers may have significantly contributed the high nitrate values although the influence of dust accumulation in the rain samples between the rains events cannot be ignored either.

\section{Summary}

A database set of oxygen and hydrogen isotopes measurements on PPT at 11 rainfall stations across Jordan shows significant variations that reflect the influence of environmental (climatic and geographic) controls and anthropogenic impacts. The WMV of $\delta^{18} \mathrm{O}$ and $\delta \mathrm{D}$ values was used to calculate a LMWL $\left(\delta \mathrm{D}=6.27 * \delta^{18} \mathrm{O}+11.40\right)$ to be used as a reference for hydrological studies in the country. The isotope results provided significant information regarding relationship between precipitation and some climatically relevant parameters, such as altitude effect. These isotope records for precipitation also contribute significantly to atmospheric modeling the area, there poor correlation between $\delta^{18} \mathrm{O}$ and d-excess implies that more data are required to better understand the true mass trajectories and the factors influencing them. Average annual precipitation decreased after 1988, which reflects a slight change in the climate. The current average tritium level in precipitation is almost equal to natural levels of the global atmosphere. Tritium concentrations in PPT from Rabba are twofold higher than average tritium levels throughout the country, which is likely attributed to possible leakage from a nuclear research facility in the region that located in close proximity from Rabba. The elemental chemistry of rains demonstrates wide variation of TDS concentrations. Variations in salinity are influenced by different factors, such as desert dust, aerosols, and amounts of precipitation. 
Fig. 10 Piper diagram of precipitation

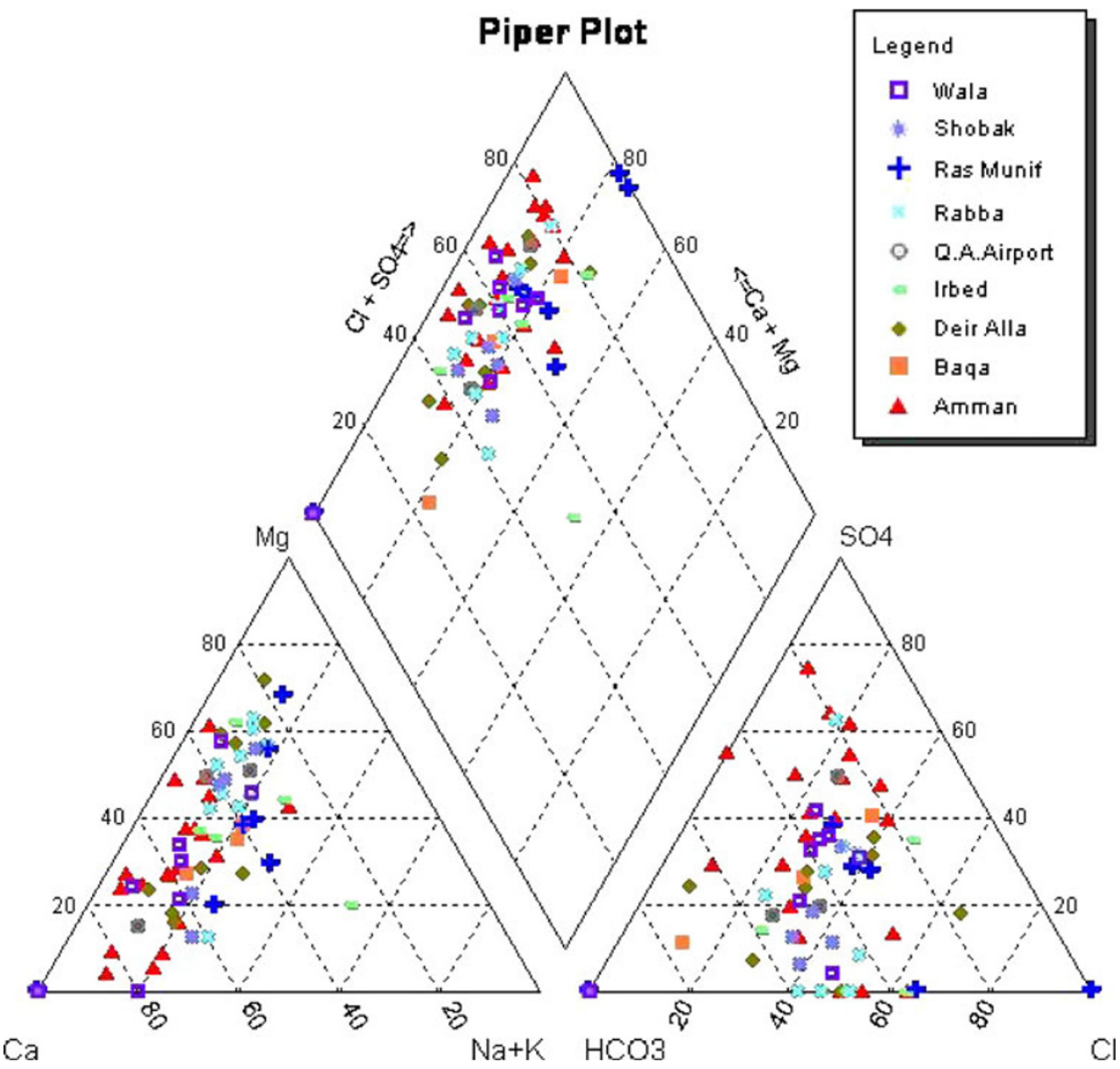

distribution, and reproduction in any medium, provided the original author(s) and the source are credited.

\section{Appendix}

See Table 6.

Open Access This article is distributed under the terms of the Creative Commons Attribution License which permits any use, possible without the support of Dr. Kheir Al Hadidi Director of Water Resources of Water Authority of Jordan for some of the data sampling and to Eng. Suzan Kilani, Director of Water Authority Labs, for providing the laboratory facilities to analyze the isotope data. Special thanks to Dr. Elias Salameh of University of Jordan for sharing some of the chemical data of the precipitation.

Table 6 Isotopic composition of rain water samples

\begin{tabular}{llllllllllrr}
\hline ID & $\delta^{18} \mathrm{O}$ & \multicolumn{1}{l}{$\delta \mathrm{D}$} & $\mathrm{d}(\%)$ & $\mathrm{ID}$ & $\delta^{18} \mathrm{O}$ & $\delta \mathrm{D}$ & $\mathrm{d}(\% \mathrm{o})$ & $\mathrm{ID}$ & $\delta^{18} \mathrm{O}$ & $\delta \mathrm{D}$ & $\mathrm{d}(\% \mathrm{o})$ \\
\hline 1 & -4.81 & -19.05 & 19.43 & 5 & -5.95 & -25.77 & 21.85 & 8 & -6.92 & -31.16 & 24.23 \\
1 & -4.94 & -20.14 & 19.41 & 5 & -6.02 & -26.65 & 21.47 & 9 & -4.42 & -6.60 & 28.76 \\
1 & -1.53 & -3.92 & 8.29 & 5 & -6.08 & -27.58 & 21.09 & 9 & -4.69 & -19.93 & 17.60 \\
1 & -3.81 & -18.03 & 12.46 & 5 & -8.25 & -39.08 & 26.94 & 9 & -2.97 & -7.17 & 16.59 \\
1 & -5.93 & -30.13 & 17.28 & 5 & -7.48 & -32.91 & 26.97 & 9 & -3.50 & -11.01 & 17.01 \\
1 & -3.68 & -15.38 & 14.09 & 5 & -6.26 & -29.34 & 20.78 & 9 & -6.47 & -26.76 & 25.00 \\
1 & -3.38 & -7.92 & 19.13 & 5 & -4.18 & -12.45 & 20.96 & 9 & -7.06 & -30.60 & 25.92 \\
1 & -3.16 & -13.91 & 11.36 & 5 & -5.95 & -25.28 & 22.35 & 9 & -6.43 & -25.70 & 25.76 \\
1 & -2.86 & -8.80 & 14.08 & 5 & -5.94 & -26.28 & 21.25 & 9 & -6.37 & -28.73 & 22.24 \\
1 & -4.04 & -17.01 & 15.34 & 5 & -6.38 & -29.68 & 21.32 & 9 & -7.41 & -33.90 & 25.40 \\
1 & -3.67 & -13.98 & 15.37 & 5 & -6.18 & -26.53 & 22.91 & 9 & -4.83 & -18.80 & 19.84 \\
\hline
\end{tabular}


Table 6 continued

\begin{tabular}{|c|c|c|c|c|c|c|c|c|c|c|c|}
\hline ID & $\delta^{18} \mathrm{O}$ & $\delta \mathrm{D}$ & $\mathrm{d}(\%)$ & ID & $\delta^{18} \mathrm{O}$ & $\delta \mathrm{D}$ & $\mathrm{d}(\%)$ & ID & $\delta^{18} \mathrm{O}$ & $\delta \mathrm{D}$ & $\mathrm{d}(\% 0)$ \\
\hline 1 & -3.66 & -14.85 & 14.42 & 5 & -6.57 & -20.63 & 31.93 & 9 & -6.90 & -38.22 & 17.02 \\
\hline 1 & -3.65 & -15.01 & 14.19 & 5 & -5.57 & -15.11 & 29.48 & 9 & -6.90 & -28.25 & 26.93 \\
\hline 1 & -4.14 & -15.49 & 17.65 & 6 & -4.28 & -9.91 & 24.37 & 9 & -6.11 & -20.37 & 28.51 \\
\hline 1 & -2.72 & -12.04 & 9.76 & 6 & -4.79 & -15.57 & 22.74 & 10 & -7.59 & -32.90 & 27.85 \\
\hline 2 & -7.63 & -48.00 & 13.04 & 7 & -5.25 & -19.25 & 22.73 & 10 & -7.46 & -34.88 & 24.81 \\
\hline 2 & -1.42 & 12.70 & 24.06 & 7 & -5.64 & -21.02 & 24.13 & 10 & -7.09 & -34.10 & 22.61 \\
\hline 2 & -1.50 & 0.70 & 12.70 & 7 & -7.13 & -35.15 & 21.92 & 10 & -6.71 & -30.22 & 23.47 \\
\hline 2 & -2.21 & -1.50 & 16.18 & 7 & -6.47 & -31.21 & 20.58 & 10 & -7.77 & -38.40 & 23.77 \\
\hline 2 & -2.31 & -3.82 & 14.67 & 7 & -6.38 & -28.14 & 22.94 & 10 & -6.23 & -22.83 & 26.98 \\
\hline 3 & -5.02 & -20.05 & 20.14 & 7 & -3.33 & -6.30 & 20.34 & 10 & -6.91 & -31.89 & 23.38 \\
\hline 3 & -5.58 & -22.96 & 21.67 & 7 & -5.12 & -20.91 & 20.08 & 10 & -6.75 & -31.11 & 22.92 \\
\hline 3 & -5.47 & -24.10 & 19.67 & 7 & -4.73 & -23.60 & 14.26 & 10 & -4.44 & -15.88 & 19.67 \\
\hline 3 & -5.01 & -24.01 & 16.11 & 7 & -5.98 & -27.30 & 20.52 & 10 & -6.37 & -27.59 & 23.36 \\
\hline 3 & -6.01 & -28.75 & 19.33 & 8 & -4.12 & -14.18 & 18.81 & 10 & -7.42 & -35.68 & 23.70 \\
\hline 3 & -7.93 & -43.47 & 20.01 & 8 & -7.06 & -30.82 & 25.69 & 10 & -7.13 & -34.30 & 22.77 \\
\hline 4 & -1.39 & -2.93 & 8.22 & 8 & -6.69 & -27.64 & 25.91 & 10 & -6.81 & -29.47 & 25.01 \\
\hline 4 & -7.51 & -36.74 & 23.31 & 8 & -6.11 & -25.30 & 23.55 & 10 & -7.06 & -30.97 & 25.49 \\
\hline 4 & -9.27 & -51.98 & 22.18 & 8 & -6.95 & -35.42 & 20.19 & 10 & -7.12 & -25.47 & 31.51 \\
\hline 4 & -3.19 & -9.09 & 16.45 & 8 & -6.81 & -30.75 & 23.74 & 11 & -7.91 & -40.13 & 23.15 \\
\hline 4 & -7.24 & -38.14 & 19.76 & 8 & -6.77 & -26.75 & 27.40 & 11 & -7.37 & -34.46 & 24.50 \\
\hline 4 & -3.86 & -15.56 & 15.34 & 8 & -6.59 & -29.51 & 23.20 & 11 & -6.19 & -23.66 & 25.90 \\
\hline 4 & -6.79 & -32.05 & 22.26 & 8 & -6.47 & -27.56 & 24.18 & 11 & -6.54 & -27.51 & 24.83 \\
\hline 4 & -5.11 & -25.78 & 15.09 & 8 & -7.97 & -31.87 & 31.91 & 11 & -8.48 & -43.38 & 24.44 \\
\hline 4 & -2.44 & -4.43 & 15.06 & 8 & -3.57 & -8.11 & 20.42 & 11 & -6.86 & -34.80 & 20.06 \\
\hline 4 & -8.51 & -52.81 & 15.24 & 8 & -7.49 & -33.13 & 26.78 & 11 & -6.20 & -28.70 & 20.87 \\
\hline 4 & -3.22 & -12.69 & 13.07 & 8 & -7.06 & -35.68 & 20.78 & 11 & -5.92 & -27.54 & 19.84 \\
\hline 4 & -3.45 & -12.50 & 15.06 & 8 & -6.75 & -30.31 & 23.65 & 11 & -6.65 & -30.20 & 23.01 \\
\hline 5 & -7.89 & -37.92 & 25.20 & 8 & -6.70 & -28.71 & 24.88 & 11 & -5.96 & -23.81 & 23.86 \\
\hline 5 & -6.76 & -29.50 & 24.57 & 8 & -6.37 & -26.45 & 24.54 & 11 & -5.69 & -19.66 & 25.89 \\
\hline
\end{tabular}

\section{References}

Bajjali W (1990) Isotopic Characteristic of Precipitation in Jordan, International Symposium on the Use of Isotope Technique in Water Resources Development Vienna, Austria, IAEA-SM-319/ $61 \mathrm{P}$

Bajjali W (1994) Hydrochemistry and isotope hydrology of thermal groundwaters in northern Jordan. Ph.D. Thesis, University of Ottawa, Canada

Bajjali W, Clark ID, Fritz P (1997) The artesian thermal groundwaters of Northern Jordan: insights to their origin and subsurface history. J Hydrol 192(1-4):355-382

Boyle EA (1997) Cool tropical temperatures shift the global $\delta^{18} \mathrm{O}-\mathrm{T}$ relationship: an explanation for the ice core $\delta^{18} \mathrm{O}$-borehole thermometry conflict? Geophys Res Lett 24:273-276

Clark ID, Fritz P (1997) Environmental isotopes in hydrogeology. CRC Press/Lewis Publishers, Boca Raton, p 328

Craig H (1961) Standards for reporting concentrations of deuterium and oxygen-18 in natural water. Science 133:1833-1834

Dansgaard W (1964) Stable isotopes in precipitation. Tellus 16:436468

Dore MHI (2005) Climate change and changes in global precipitation patterns: what do we know? Environ Int 31(8):1167-1181
Gat JR (1980) The isotopes of hydrogen and oxygen in precipitation. In: Fritz P, Fontes J-Ch (eds) Handbook of Environmental Isotope Geochemistry, vol 1., The Terrestrial Environment A. Elsevier, Amsterdam, pp 21-48

Gat JR, Carmi I (1970) Evolution of the isotopic composition of atmospheric waters in the Mediterranean Sea area. J Geophys Res 75:3039-3048

Gat JR, Carmi I (1987) Effect of climate changes on the precipitation patterns and isotope composition of water in a climate transition zone-case of the eastern Mediterranean Sea area. In: The influence of climate change and climate variability on the hydrologic regime and water resources. IAHS Publ. no. 168:513-523

Gat JR, Dansgaard W (1972) Stable isotope survey of the fresh water occurrences in Israel and the Northern Jordan Rift valley. J Hydrology 16:177-211

Gat JR, Bowser CJ, Kendall C (1994) The contribution of evaporation from the Great Lakes to the continental atmosphere: estimate based on stable isotope data. Geophys Res Lett 21(7):557-560

Hadidi K, Ismail M (2010) International Workshop on Aquifers Coastal Management: vulnerability and adaptation to the impacts of the climate change on the Southern Mediterranean Basin. Rabat, Morocco 
Hartley P (1981) Deuterium/hydrogen ratios in Australian rainfall. J Hydrol 50:217-229

IPCC (2007) Climate change 2007: the physical science basis. In: S Solomon, D Qin, M Manning (eds) Contribution of Working Group I to the Fourth Assessment Report of the Intergovernmental Panel on Climate Change

Meteorological Department of Jordan (1998) Jordan Climatological Data handbook. The Hashemite kingdom of Jordan, Amman, Jordan, p 104

Rozanski KL, Araguás-Araguás, Gonfiantini R (1993) Isotopic patterns in modern global precipitation. In: P. K. Swart et al (eds)
Climate Change in Continental Isotopic Records. Geophys Monogr Ser, vol. 78, AGU, Washington, DC, pp 1-36

Stewart MK (1975) Stable isotope fractionation due to evaporation and isotope exchange of falling water drops. Application to atmospheric processes and evaporation of lakes. J Geophys Res 80:1138-1146

U.S. Environmental Protection Agency (2010) www.epa.gov/radiation/ radionuclide/tritium.html

Zahn A, Barth V, Pfeilsticker K, Platt U (1998) Deuterium, oxygen18 , and tritium as tracers for water vapour transport in the lower stratosphere and tropopause region. J Atmos Chem 30:25-47 